\title{
New Healthy Settlements Responding to Pandemic Outbreaks: Approaches from (and for) the Global City
}

\author{
Luca Maria Francesco Fabris, Federico Camerin, \\ Gerardo Semprebon, Riccardo Maria Balzarotti
}

\begin{abstract}
The essay critically addresses several solutions and strategies for tackling urban inequalities to uphold the recent "right to the "healthy' city" spatial paradigm based on early social science works by Emily Skinner and Jeffrey R. Masuda (2013) and then developed as a urban planning component by the interdisciplinary research group Barcelona Lab for Urban Environmental Justice and Sustainability (2019). The authors propose a transdisciplinary approach in dealing with city renewal-regeneration and the safer use of its spaces. The interrelation between urbanism and architecture, including environmental design, mobility, and social relations, among others, would merge to imagine a more ecologically and socially balanced urban milieu. The paper analyses four specific case studies assumed as proper approaches in dealing with the pandemic, critically reflecting on the application of "Superblocks," "Tactical Urbanism," and "15-minute City" concepts by illustrating and comparing their application in three global cities (respectively Barcelona, Beijing, and Milan). In a nutshell, the authors demonstrate that these policies have their crucial feature in being effective applications formulated for different contexts, proposing successful strategies to overcome health, environment, and mobility issues in all the contemporary global cities.
\end{abstract}

Keywords: 15-minute city, environmental resilience, global and healthy city, Superblocks, tactical urbanism

Although the city-making process since the mid-nineteenth century should have been driven by diseases and pandemics prevention to create a new 
safe built environment, the hygienic criteria had been manipulated and/or used mostly to implement a capitalist-led urbanization and land speculation. This dynamic can be used to describe the lldefonso Cerdà's Plan for the Extension of Barcelona, which was a model of key importance at that era ${ }^{1}$ Among the consequence of this dynamic, the materialization of the so-called "global city" has taken place, ${ }^{2}$ causing a striking repercussion in terms of socio-spatial segregation, more inequality between people and territories, leading to waves of migration from territory to territory, and serious environmental issues that stand out among the consequence of this dynamic, all of which have been brought into the foreground with the 2020 pandemic outbreak. The authors claim that the outbreak of COVID-19 highlights the necessity to deal with the dark side of the global city and the necessity to guarantee a new a healthy and safe life for the citizenry. As recently stated by Jonas Bylund, Johannes Riegler, and Margit Noll, "urban areas and policy are challenged not just with resilience in a technical sense, but with the robustness of their ethical value based around democracy and human rights by increasing turbulence and shifting grounds in terms of climate as well as societal dynamics." ${ }^{3}$

With this in mind, the authors reflect on the application of innovative concepts such as the "Superblocks" (Barcelona and Beijing) and the "Tactical Urbanism" (Milan), ${ }^{4}$ considered as valid methodological processes to implement the "right to the "healthy" city" ${ }^{5}$ (see Table 1). On the one hand, Superblocks are assembled to reduce traffic and increase liveable community and public space and, on the other hand, Tactical Urbanism is a neighbourhood-scaled approach using short-term, low-cost, and scalable interventions and policies (Table 1). Following the initial pandemic outbreak

\begin{tabular}{|c|c|c|c|c|c|}
\hline $\begin{array}{l}\text { Case } \\
\text { study }\end{array}$ & $\begin{array}{l}\text { Concept } \\
\text { applied }\end{array}$ & Year & Costs (M€) & $\begin{array}{l}\text { Methods of } \\
\text { survey }\end{array}$ & Mitigation Covid-19 impact \\
\hline Barcelona & Superblocks & $\begin{array}{l}2016 \text { - } \\
\text { ongoing }\end{array}$ & 3.5 (Poblenou) & $\begin{array}{l}\text { Desk research } \\
\text { activity and } \\
\text { fieldwork }\end{array}$ & $\begin{array}{l}\downarrow \text { private motorized transport } \\
\uparrow \text { public-health-friendly urban } \\
\text { design (green surface) } \\
\uparrow \text { sense of community, security, } \\
\text { safety and well-being }\end{array}$ \\
\hline Beijing & Superblocks & $\begin{array}{l}2000 \text { - } \\
\text { ongoing }\end{array}$ & unknown & $\begin{array}{l}\text { Desk research } \\
\text { activity and } \\
\text { interviews }\end{array}$ & $\begin{array}{l}\downarrow \text { private motorized transport } \\
\uparrow \text { public-health through access control } \\
\uparrow \text { sense of community, security, } \\
\text { safety and well-being }\end{array}$ \\
\hline Milan & $\begin{array}{c}\text { Tactical } \\
\text { urbanism }\end{array}$ & $\begin{array}{c}2018 \text { - } \\
\text { ongoing }\end{array}$ & $\begin{array}{l}0.05 \text { to } 0.15 \\
\text { per each } \\
\text { intervention } \\
\text { (estimated) }\end{array}$ & $\begin{array}{l}\text { Desk research } \\
\text { activity and } \\
\text { interviews }\end{array}$ & $\begin{array}{c}\downarrow \text { private motorized transport } \\
\uparrow \text { sense of community, security } \\
\text { proximity to public spaces } \\
\uparrow \text { use of bikes and electric scooters }\end{array}$ \\
\hline
\end{tabular}

Table 1. The case study brief. 
of 2020, a growing number of inquiries are pinpointing Superblocks and Tactical Urbanism as solutions to overcome the economic, social, and urban inequalities of the Global City. In fact, in July 2020 Barcelona and Milan joined the "Global Mayors COVID-19 Recovery Task Force" to improve public health, reduce inequality, and address the climate crisis in thirty-eight cities across the world through the application of the 15-minute city), ${ }^{6}$ while Beijing has proved the social and health validity of its closed Superblocks.

These multidisciplinary strategies, all planned before the outbreak of the current pandemic, apparently constitute a range of common solutions dealing with the critical issues present in these diverse urban realities (i.e., increasing problems of congestion and air pollution, a lack of inclusive communities and healthy public spaces) and the necessity to improve local sustainability and promote urban resilience. At the same time, the outbreak of the COVID-19 seems to have accelerated the debate on these innovative solutions to be exported across the world for their pioneering ideas. COVID-19 meant significant changes to public spaces to enable safe mobility and to overcome private-car use, leading the city towards slow mobility and shared transportation forms providing healthy spaces for the citizenry.

\section{BARCELONA'S SUPERBLOCKS}

On the ground of the so-called "Ecosystemic Urbanism" principles, ${ }^{7}$ the idea of Superblock (supermanzana in Spanish; superilles in Catalan) refer to the artificial creation of a $400 \mathrm{~m} \times 400 \mathrm{~m}$ [1,312 ft. x 1,312 ft.] urban cell including open spaces (streets, sidewalks, squares), thus corresponding to nine square-shaped blocks of Cerdà's Extension. ${ }^{8}$ The aim of this "neighbourhood unit" is to reverse car dependency of Barcelona into sustainable, healthy, compact, and connected spaces with a mixed land-use and high potential for social capital. ${ }^{9}$ Through the 2013-18 Urban Mobility Plan of Barcelona, Superblocks were developed by a collaboration between the Barcelona City Council and a public consortium called the Urban Ecology Agency (BCNEcologia) along with other public agreements, initiatives, and strategic tools (i.e. the "Citizen Commitment to sustainability - a More Sustainable Barcelona 2012-22"). ${ }^{10}$

Significant impacts are expected with the Superblocks approach implementation, but its comprehensive implementation is far from complete. As of today, the innovative neighbourhood model has been effectively implemented in six Superblocks while the total prevision is to create 503 Superblocks within the whole city. By screening the data on Superblocks' documentation ${ }^{11}$ and their dissemination through research papers, ${ }^{12}$ among the pivotal change that the 503-Superblock system pursues stand out the decrease of private motorized transport by $19.2 \%$ (with a consequent improvement of air quality 
and less urban noise and the prevention of 667 premature deaths) and the green surface increase from $2.7 \mathrm{~m}^{2} /$ inhab. to $6.3 \mathrm{~m}^{2} /$ inhab. for the whole area of Extension district and up to $7.6 \mathrm{~m}^{2} / \mathrm{inhab}$. in Sant Martí district. Also, in an Eixample-shaped urban cell the reduction of the current heat island effect should reach $-35.9 \%$, and the increase of public space green, the blocks' interior patio's green and green covers should be $+35.8 \%$.

\section{The Poblenou Superblock}

In September 2016 the first Superblock developed in Barcelona in the Poblenou District. ${ }^{13}$ The following transformations have been carried out by 2017: the dedication of $13,350 \mathrm{~m}^{2}$ (143,698 sq.ft.) of public spaces for pedestrian use, the planting of 212 new trees, the installation of more than 300 benches, and the launching of a growing number of outdoor cultural activities in the new playground areas of $538 \mathrm{~m}^{2}$ [5791 sq.ft.] and the thirty-seven new premises for activities at street level. The renewal of the existing built environment resulted in an increase of $2.6 \%$ in traffic in the four perimeter roads, while the vehicle circulating within interior streets dropped by $58 \%$. Within the internal streets, there has been an average reduction in daytime noise levels of five decibels. Going deeper into the impact of the Poblenou unit, specific fieldwork by one of the authors in August 2017, August 2018, February 2019, and September 2020 (statistical reference sample indicated by "Poblenou Veïns i Veïnes Association") substantially confirm the findings of the work by Jacopo Scudellari, Luca Staricco, and Elisabetta Vitale Brovarone (2019), ${ }^{14}$ thus highlighting a number of issues in the implementation phase of this Superblock. As both residents and non-residents recognize the need to change the approach to the city in regards to sustainability, they have changed their opinion in favour of the Superblock. In this context, the implementation process, the overlapping of Superblocks to the existing built environment, and the possible side effects in terms of rising real estate values can be recognized as critical points of Superblocks system also in the post-COVID-19 emergency.

As for governance, the high cost of implementation in Poblenou (€3.5 million) requires a considerable budget availability to be expanded in the whole city. Also, the launching of the initiative was claimed to have poorly involved local residents in the process, thus causing protests against the lack of proper participation by decision-makers. As a consequence, the next pilot projects of Superblocks have been accompanied by open debates with citizens. The COVID-19 challenge sped up the urgency of extending Superblocks across Barcelona, and thanks to the European Investment Bank funding support for cities green recovery, €23.75 million will be used to implement Superblocks. ${ }^{15}$ As for the overlapping of Poblenou unit to the existing built environment, firstly the mobility system showed incoherence when it changed the traffic flows without implementation in the whole system. Secondly, cycle-lanes were not fully reallocated at the 
beginning of the implementation process, and in some cases the existing ones were removed in favor of walkable spaces, thus generating conflicts between pedestrians and cyclists. Thirdly, no underground parking replaced the removed parking lots.

As for the risk of rising real estate values, two concerns arose regarding the possible risk of gentrification. First, the housing cost. ${ }^{16}$ It is found that the price per square meter of second-hand houses for sale in El Parc $i$ la Llacuna del Poblenou neighborhood grew from $€ 3,761 / \mathrm{m}^{2}$ of 2016 to $€ 4,144 / \mathrm{m}^{2}$ of 2020 , thus exceeding the average price of Sant Martí district (from $€ 3,382 / \mathrm{m}^{2}$ of 2016 to $€ 3.697 / \mathrm{m}^{2}$ of 2020) and the average prices of Barcelona (from $€ 3,478 / \mathrm{m}^{2}$ to $€ 4,111 / \mathrm{m}^{2}$ ). Second, the rent costs, which are only available for the year 2020. ${ }^{17}$ In El Parc i la Llacuna del Poblenou the cost $€ /$ month is $€ 969,1 /$ month, and the cost $€ / \mathrm{m}^{2} /$ month reaches $€ 14,2 /$ $\mathrm{m}^{2} /$ month, in the Sant Martí district €954,1/month and €14,0/ $\mathrm{m}^{2} / \mathrm{month}$. Despite the increase of prices, the neighborhood seems to follow real estate market trends unrelated to the application of the Superblock. Moreover, in the Catalan Parliament passed a law regulating rent prices on new housing contracts signed from its approval (September 2020) to guarantee accessibility in sixty Catalan municipalities, including Barcelona. ${ }^{18}$
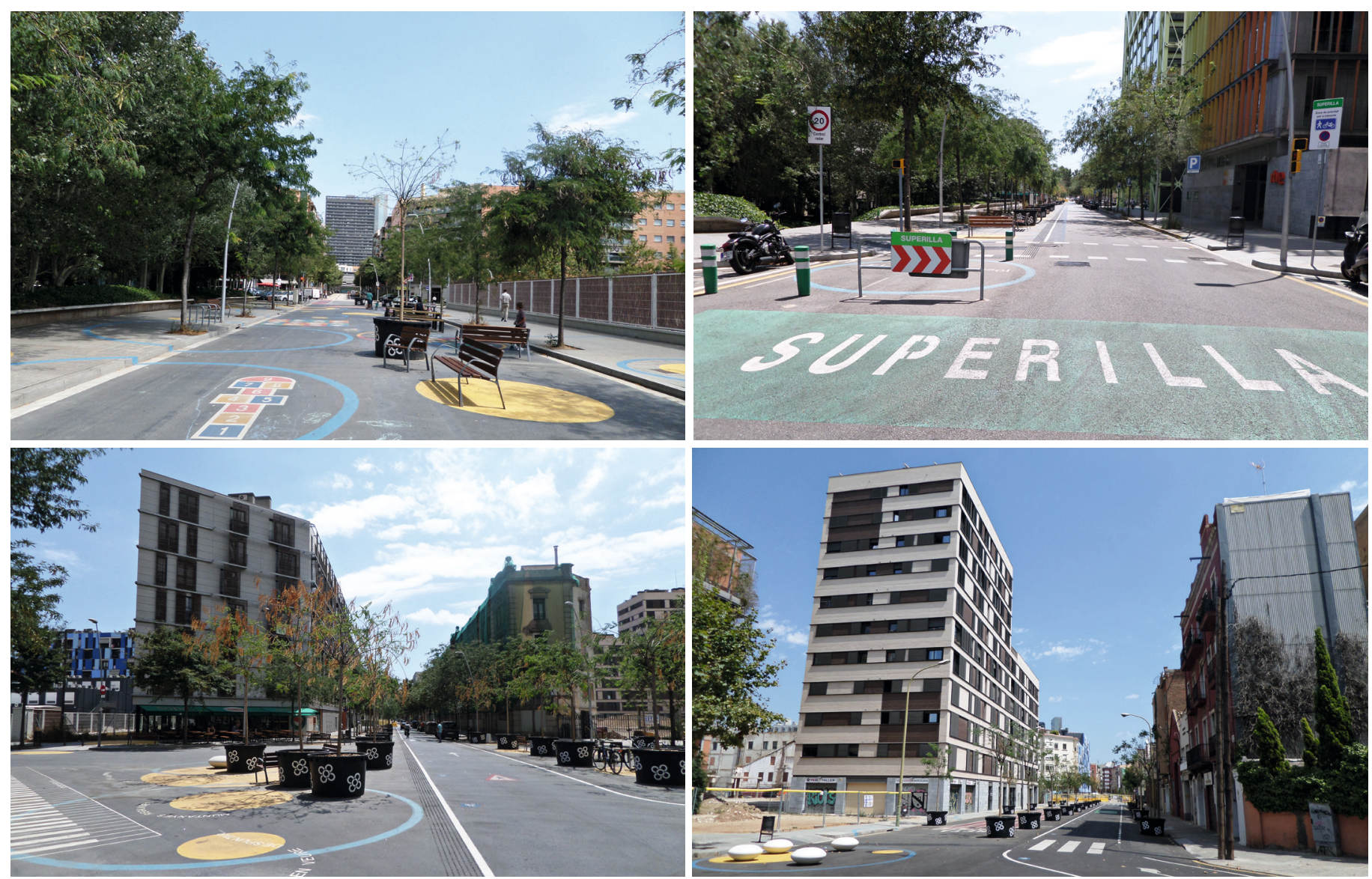

Figures 1-4. Views of the Poblenou's Superblock. 
To sum up, despite some early push back when the change was not broadly welcomed by residents and non-residents, interviews confirm that despite the difficulties to accept a change of habits, citizens have grown to accept the need for Barcelona to become more environmentally friendly. The implementation of the Superblock has obviously added quality to the affected area, and what people require of policymakers are policies dealing with every form of inequalities and socio-spatial segregation at neighbourhood and city scale.

\section{The Challenges of Superblocks after the COVID-19 Outbreak in Barcelona}

As demonstrated by the Poblenou Superblock unit, changes in the existing urban environment require citizens to be willing to modify their behavior and perspectives in order to make Superblocks work efficiently. In this context, a top-down imposition without previous consultation with local residents can restrain innovation and social progress in the post-pandemic city. Governance transparency and a bottom-up approach in dealing with such transformations will ensure fair use of resources, accelerate the Superblock implementation, and guarantee a continuous engagement of citizens with local government spokespersons. Since the quarantine, all interviewees valued the application of the Superblock system positively as it strengthened the sense of community, security, safety, and well-being, plus the necessity for Barcelona to invest in public-health-friendly urban design. Other factors that played an important role in the success of the Superblock initiatives after the pandemic outbreak: the provision of new friendly features to the internal streets (such as urban furniture and greenery); the reassessment of surrounding roads (such as the installation of a trafficmanagement system to deal with the growing traffic in the surroundings of Superblocks); and the granting of substantial capital investments, which today are quite difficult to implement in the short-term due to the persistent lack of public funding caused by so-called "urban austerity." 19

Starting from the quarantine and the successive gradual re-opening of the city, the interviewees pointed out that Superblock can mitigate the adverse economic, social, and urban effects of COVID-19 in the following ways. The Superblock deals with density guaranteeing open public spaces for residents and city users maintaining a physical distance. The reduction of space for private vehicles and the consequent incorporation of new walkable spaces provided increased access to shops and services. These changes have contributed to an increase in the sense of community and social sustainability even during the lockdown and improved the performance, flexibility, and durability of the spaces that individuals and families occupy while respecting distance. The measures adopted in Poblenou, such as speed limits restrictions and increasing parking costs, lowered car use within the Superblock unit and thus incited the use of slow means of transport and buses. The citizens' change of behaviour, also forced by COVID-19, improved the recognition of new accessibility for the 
post-pandemic city, basically on foot and bike. The Superblock, thereby, results in 2020 as a feasible solution to improve mental and physical health associated with lower levels of pollution and traffic (Figs. 1-4).

\section{CHINESE URBANISM: THE CASE OF BEIJING}

Among extra-European contexts, Chinese urbanism represents an interesting source of comparison, here observed in the case of Beijing's Superblocks. The origin of Superblocks may be identified in the danwei, the well-known work units inspired by Soviet models and systematically applied during the Maoist era aimed at turning cities into production centers. These compounds were conceived as self-reliant blocks integrating the main aspects of a neighborhood community, in order to optimize the productivity of the Chinese workforce during the hard times of the newborn People's Republic of China. Within the danwei, workers could hypothetically - but often truly - live and work without leaving the block. As observed by Campanella, "the Maoist city was thus really more a collection of tiny urban villages than a metropolis in the Western sense, with a heterogeneous, finely grained texture of land use." ${ }^{20}$ Across the following economic cycles, the urban model gradually shifted to meet the growing housing demand, without losing the introverted character permeating the Chinese residential ideal, traceable in many historical examples beyond the Maoist city. ${ }^{21}$ The main traits of large-scale Chinese urbanism can be addressed considering the last stage of this long-lasting trajectory: the Superblocks, which represent the optimized and tested answer to the housing market demands. ${ }^{22}$

\section{Chinese Superblocks Today}

A distinctive character of Chinese Superblocks is their size. As remarked by Renee Y. Chow, "a typical block in Beijing is equivalent to twenty-eight in New York or thirty-one in Barcelona." ${ }^{23}$ The thrusts lying behind this process of oversizing are mainly economic and engineering. In this way, developers - which often consist of parastatal companies buying the users' rights for a specific duration - can optimize the construction process reducing the costs of time and resources. The blocks' infrastructural system is charged to the developer, resulting in consistent gains to the State, which remains the owner of the land. These vast parcels of land are treated like empty surfaces to be re-designed by implementing a tabula rasa approach, which gives priority to realization speed and market demands. The logical consequence is the repetition ad libitum of standard housing typologies, such as thirty or forty high-rise buildings replicated ubiquitously to maximize sunlight exposure and the high number of dwellings. ${ }^{24}$ Chow ironically addressed the design of the Superblock as a game of "shifting buildings like chess pieces." ${ }^{25}$ The borders of the Superblocks are entirely fenced, preventing any spatial relationships with the external roads. Bus stops and bike racks are located in the proximity of the gates, where private 
surveillance services provide security and assistance. The space between the buildings is amorphous, lacking a clear spatial structure. It is occupied by parking lots, playgrounds, random vegetation, temporary markets, or small pavilions hosting services such as grocery stores, laundries, elderly care, nursery, and so on for the community living inside the block. Social relations grow inside the Superblocks and, despite inaccessibility to the public, these portions of land host confined micro-worlds where everyday life is unveiled, and citizens become part of the larger fabric of the city.

The Chinese Superblocks model matches the interests of the State, who gains from the sale of the land use rights, the developers, who exploit the housing demand, and the citizens, in particular the rising middle class, which is attracted by the amenities of modern houses and the safety of gated communities. The system works from a socio-economic point of view. On the other side, the price to pay is the flattening of cultural diversities. The imposition of standardized solutions makes the city reproduce itself endlessly without elements of discontinuity. Since this model is not going to change in the following years, maybe decades, ${ }^{26}$ the question for urban quality - and today urban health - can be more easily tackled by considering softer forms of urbanisms more sensible to the use of spaces rather than their spatial characters.

\section{Challenges for Superblocks: From Gated to Responsive Communities}

Considering the recent COVID-19 outbreak, the possibility of controlling the fluxes of people entering and leaving the Superblocks may represent an intelligent device if supported by an effective assistance system. The presence of a few entrances makes the Chinese Superblocks easy to isolate in case of new outbreaks or other emergencies requiring quarantine measures. ${ }^{27}$ At the same time, the Superblocks are big enough to rearrange in a relatively easy way the community's routine. The use of colored codes regulating the possibility to move in China has already been amply documented and, going beyond ethical dilemmas about restriction measures; they proved to be effective in protecting the health of the population. The gated community already existing may turn to be useful in pandemic prevention or another form of social or health emergency. As planners and architects, an interesting question concerns how to re-imagine life and space inside these kinds of Superblocks in both circumstances, closed and open.

Even before the pandemic, as gated communities, the Superblocks had no relationship to the surrounding urban form, generating de facto a negative experience of the urban open spaces outside the fence. A possible approach toward an alternative urban experience could be to re-imagine the permeability of the Superblocks by encouraging more relations among the blocks. In this perspective, parking spaces and car circulation should be reorganized to protect and valorize soft mobility and a more friendly environment for pedestrian activities. How to turn the gated communities of 
the Superblocks into more "urban" communities re-considering the use of the existing system of open spaces represents a challenging question to planners, architects, and landscapers. Their introverted character may suggest reflecting on the central spaces inside the blocks rather than on the perimeter, by working on the performance of the open spaces. Such kinds of approaches present several advantages, such as they consider different uses according to the seasonality of human activities, are cheap and reversible and promote the pro-active engagement of the community. Regarding this, the notion of "field urbanism" coined by Chow seems not so far from the concepts of Tactical Urbanism, witnessing, despite the evident contextual difference, a cross-boundary convergence of interests in rethinking the existing urban spaces for a healthier and more livable city (Figs. 5-8).

(a)
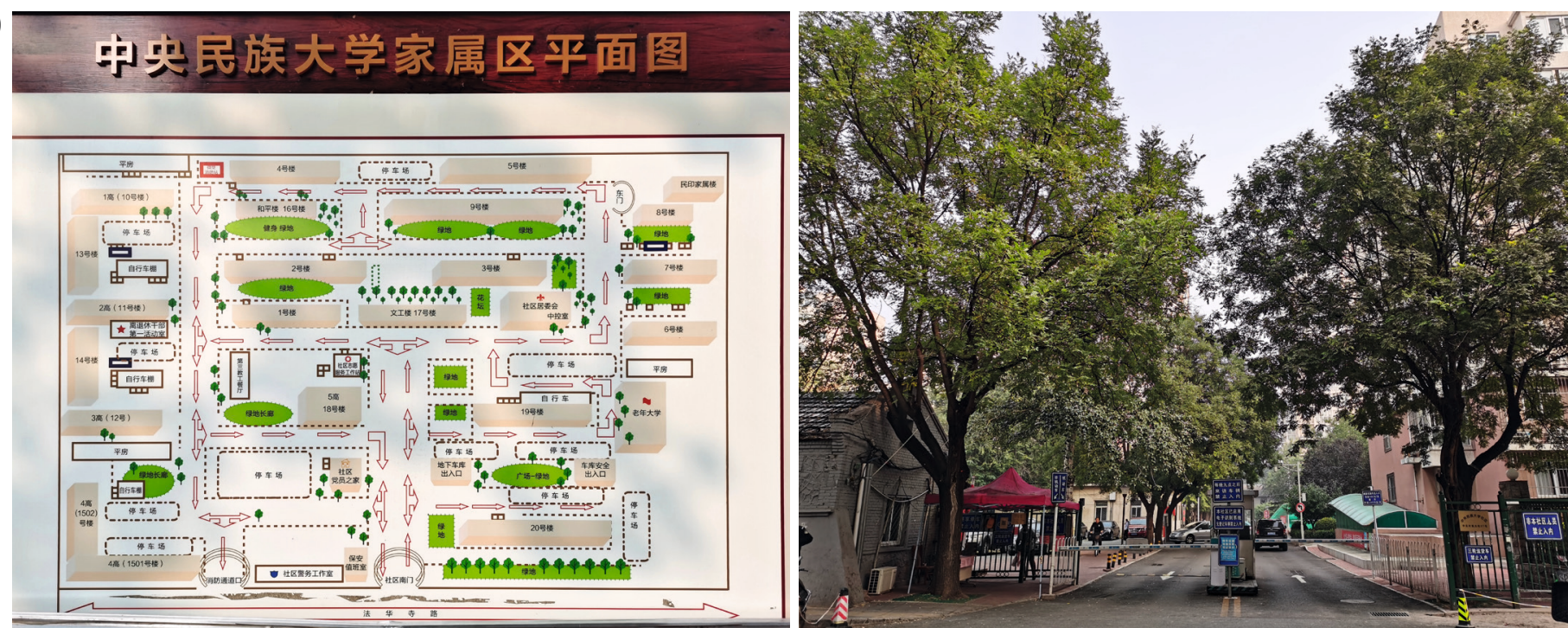

(b)

(c)
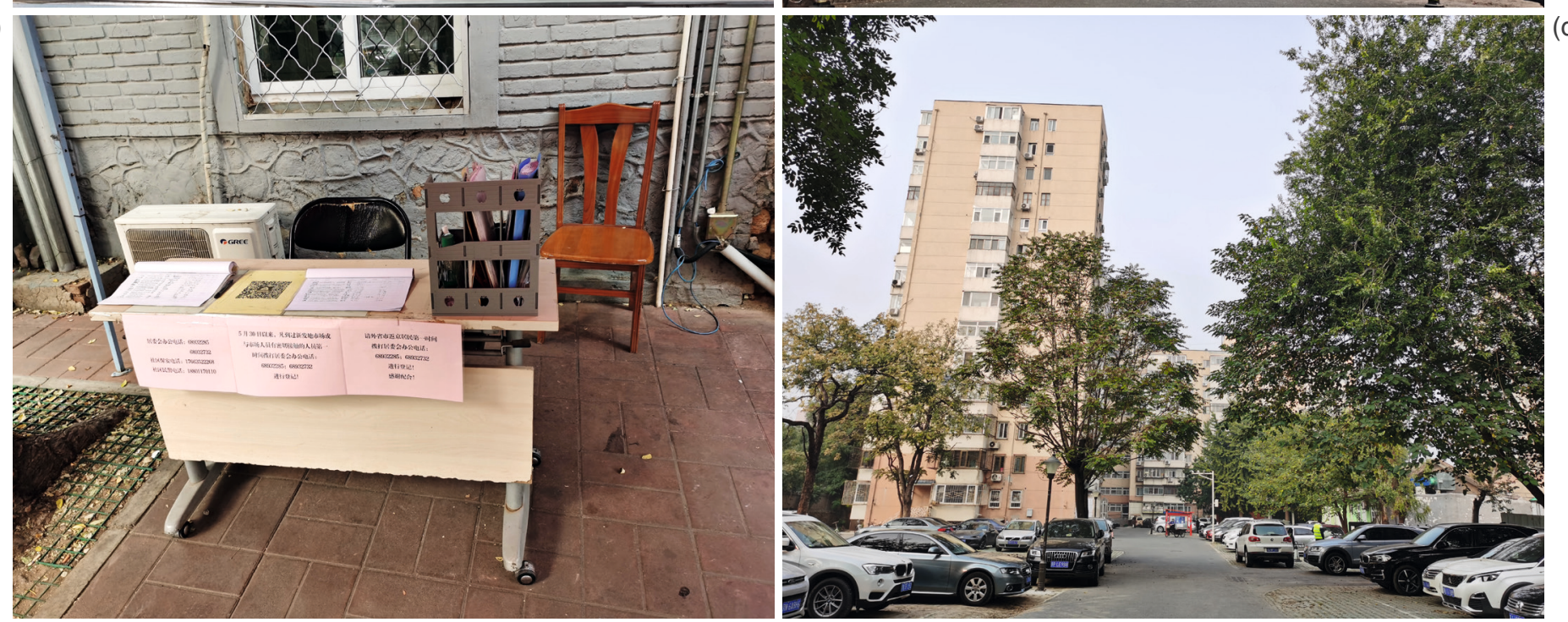

Figures 5-8. Central University Faculty and Staff Community Superblock, Beijing. Planimetry

(a), entrance gate (b), COVID-19 checkpoint at the entry (c), and general view (d). 


\section{THE MILANESE CASE STUDY}

The city of Milan is very close to the Bergamo area, one of the first regions to be hit by the COVID-19 pandemic at the beginning of March 2020. Soon after, also the Municipality of Milan contributed (and still contributes) to the spread of the virus. The impact, from a social and economic point of view, has been hard and will probably have long-term consequences. The immediate effect on the citizens was the lockdown measure that, after the first phase of almost-total home confinement, in April became slightly less strict, allowing the free movement within a $200 \mathrm{~m}$ [656 ft.] radius from home. At the end of May 2020, the local government lifted the total lockdown measures but left in place several less strict limitations. This unprecedented scenario led Milan, together with other global cities in the world, to promptly think and act on the liveability of a city under lockdown in terms of public spaces use and mobility.

\section{The Milanese Urban Planning Strategies before the COVID-19 Pandemic}

The response to give a more liveable city to the inhabitants of Milan, in this particular situation, has its origin in the planning strategy that the administration adopted years before the pandemic and that was focused over a most capillary diffusion of the public spaces and services. We can identify two strategic nodes in this process: The implementation of the new PGT (Piano di Governo del Territorio) in $2012^{28}$ - the new city master plan included the identification of the NIL (Nuclei di Identità Locale - Local Identity Cores). The NIL are an in-depth mapping of eighty-eight areas characterized by a strong local identity, much smaller than the administrative division of the city of Milan into nine sub-municipalities; The adoption of the Piano Quartieri (Neighbourhood Plans), an annual program to allocate economic resources to local intervention, which included the Piazze Aperte (Open Squares) ${ }^{29}$ project in 2018. Piazze Aperte was a project developed in collaboration with Bloomberg Associates, NACTO (National Association of City Transportation Official) and Global Designing Cities Initiatives. It aimed to recover and increase public spaces using Tactical Urbanism tools.

Tactical Urbanism employs forms of light, fast, and cheap urban interventions to improve the quantity and quality of public areas and implement infrastructures for soft mobility. It generally works by subtracting areas dedicated to the vehicular circulation and parking using movable closures realized with urban furniture and plants or ground paintings and markings. In this practical/theoretical context and with the consultancy of Janette Sadik-Khan as principal of Bloomberg Associates, the Municipality of Milan started the Piazze Aperte program in 2018. The decision was to operate with an experimental top-down approach, which is not uncommon for the Tactical Urbanism instruments, and "used by a range of actors, including governments, business and nonprofits, citizen groups, and individuals." 30 
The Municipality of Milan chose and implemented two areas in the north (Dergano) and in the south-eastern periphery of the city (Corvetto), neighborhoods lacking local urban centers and social aggregation spaces. In September 2018, the first two interventions of Tactical Urbanism in Milan were completed and opened to the citizens. The starting point for both the projects was the existence of a square connotated by the total lack of permeability, space for the pedestrian and social interactions, and urban qualities. They were both intricate agglomerations of redundant road junctions and parking lots. The two projects actively modified the car circulation, reducing the number of lanes and intersections and removing the parking lots. Instead, a new space for sociality and neighbourhood activities appeared, carved out from the existing streets, enclosing the area with potted plants, benches, table-tennis, bike-sharing stalls, and other types of urban furniture. A colourful dot pattern painted on the ground marked the new urban environment. Two new squares rose in a few months just using existing urban assets in a different way.

The reasons that led the Municipality of Milan to adopt Tactical Urbanism to increase the number and distribution of public spaces lie in the same essence of Tactical Urbanism. Mainly four aspects make this methodology suitable for the development of planning in today global cities:

- Economy: It is possible to implement a new square, a new bike lane, or a new pedestrian road with a minimal investment of public resources. The cost is reduced to the expenses to activate the process and for some urban furniture, paint, road signs, etc. The strategy works by modifying the layout of what is already existing.

- Time: The required time to activate and accomplish the process is limited. That allows the city managers to implement a vast number of interventions, skipping the long process needed for a traditional procedure and allowing them to measure the results on the field.

- Flexibility: The result of these light operations can be easily adapted at a later time. If something in the first phase is not matching the expectations or the users' experience shows better alternatives, it is possible to correct the mistakes with minimal expense in time and money.

- Radicality: The temporary and editable nature of Tactical Urbanism interventions creates the conditions for a more radical approach by the administrations.

Former advisor to Deputy Mayor for Planning, Green and Agriculture, Demetrio Scopelliti, who was one of the most prominent supporters of new forms of planning, remarked on these aspects in an interview. ${ }^{31}$ He stated that a Tactical Urbanism project requires an investment limited to tens of thousands of euros and a time span of months, compared to the hundreds of thousands of euros and a period of several years needed to implement traditional interventions. This flexibility allowed the planning designers team 
to adopt radical choices in the creation of new pedestrian plazas, and in the making of soft mobility experiments in the surrounding streets (e.g., bike lanes instead of parking, cycling flows against traffic direction, slow-traffic zones, etc.). All these aspects resulted in the possibility to propose many interventions at the same time, covering a large part of urban areas that required improvement. After the first two projects, fourteen more followed in 2019. One of the more interesting projects is located in the north-eastern periphery, in via Spoleto, a secondary road alongside the Viale Monza axis. Compared to other interventions, where a public square was already formed even if occupied by vehicles and road junctions - e.g., a pedestrian plaza rose from a five-road disordered and dangerous intersection.

In just one year and half of experimentation, the Piazze Aperte program was diffused among the city of Milan and opened to the citizens. The quickness of the realization is crucial in Janette Sadik-Kahn's vision: "reversing the atrophy afflicting our city streets requires a change-based urbanism that creates short term results - results that can create new expectations and demand for more projects." 32 The demand for more projects was, in fact, the following step. At the end of 2019, the Milan administration issued an open call for cooperation, asking citizens and associations to make proposals for new urban areas to become part of the Piazze Aperte program. The call resulted in sixty-five projects from citizens, ready to be analyzed, designed, and realized. After the first step of topdown Tactical Urbanism interventions, the process was prepared to explore bottom-up initiatives, when the COVID-19 pandemic and the ensuing lockdown happened.

\section{Milanese Urban Planning Strategies after the COVID-19 Pandemic}

The response from the Municipality of Milan to the pandemic issues was prompt and debated in the international press as a possible model for the future. ${ }^{33}$ There are mainly three reasons for the fast adoption of measures to adapt to the new condition: Milan was one of the first global cities to be affected by the lockdown and forced to be a forerunner in the application of new urban strategies; the process to develop new forms of liveable neighbourhoods was already ongoing, and the Tactical Urbanism strategies previously shown were compatible with giving fast solutions for new types of mobility and new local centralities in a healthier environment; the lockdown created an unprecedented condition of an almost total absence of vehicular traffic and, despite adverse circumstances, it was the occasion to reshape the urban mobility. However, this condition was temporary and required fast planning and implementation.

On April 30, 2020, the administration released a programmatic document called Strade Aperte (Open Streets) as a follow-up of the Piazze Aperte program. ${ }^{34}$ One of the main goals is the adoption of the "15-minute city" concept, developed by Carlos Moreno, the consultant behind the urban policies adopted by the mayor of Paris, Anne Hidalgo. ${ }^{35}$ 
Paris and Barcelona are indeed mentioned, among others, as a reference for the Strade Aperte document. It is interesting how all the objectives and tools developed by these cities are deeply connected and started before COVID-19, underlining how the pandemic worked as a driver to accelerate existing instances to have more sustainable metropolitan areas. The 15-minute City aims to organize the urban fabric to offer a variety of essential services characterized by the proximity to each neighbourhood. The metropolis should be planned, according to this vision, as a sort of aggregation of contiguous but autonomous villages, where schools, workplaces, gathering and cultural activities have a maximum distance of fifteen minutes walking or bike-riding distance from the residents' homes. During the COVID-19 pandemic, the Milan-based firm Systematica released two reports that were going in that direction, ${ }^{36}$ mapping the city of Milan based on the 15-minute accessibility to green areas and public spaces, dividing the municipal surface into three levels of access to services: "poor, intermediate" and "relevant." The maps showed some gaps in the Milan network of public spaces distribution and connection that necessitated being filled with a better displacement of open areas, linked with a more efficient system of soft mobility.

In that sense, the Tactical Urbanism toolbox with his fast, cheap, and adjustable solutions was the chosen path to move forward to the operative phase. Thanks to the previous experience of Piazze Aperte, two operations were almost immediately applied: The realization of a cycling connection along the Buenos Aires / Porta Venezia axis, one of the main points of access to the city centre from the north. Corso Buenos Aires is a wide urban boulevard with a traditional road section: "sidewalk-parking stallsthree car lanes per direction-parking stalls-sidewalk." The new cycling path rose by reshuffling the road section, removing one car lane per direction, replacing the parking spots with a bike lane and using the parked cars as a fence to separate and protect cyclists from the car traffic. It was the most significant intervention to launch a broader plan for the fast creation of at least $22 \mathrm{~km}$ [13 mi.] of temporary bike lanes with the Tactical Urbanism method; the enforcement of the law known as the Delibera Tavolini (Dehor Tables Act). ${ }^{37}$ It consists of the possibility for bars, restaurants, and commercial activities owners to claim the space facing their shops with a simplified procedure, free of charge, until the end of October 2020. This kind of occupation with dehors, garden chairs, and urban furniture is not limited to the sidewalks. It is also allowed to occupy parking lots and part of the road (where possible) or nearby urban "voids," generating in some cases a completely new perception of entire streets where the walkable area overcame the space for cars.

These first two prompt actions were intended as the beginning of a new planning approach for the city of Milan, as described in the programmatic document Strade Aperte. Micro-scale and capillary interventions, promotion of neighbourhood identities, accessibility to services and quality public 
spaces are the focal points for the development of a healthier city. It is possible to say, in a consequential vision, that if the healthy city is the "scope," the 15-minute city is the "strategy," the addition of local services and connection is the "method," and the Tactical Urbanism is the "tool" (Figs. 9-12).

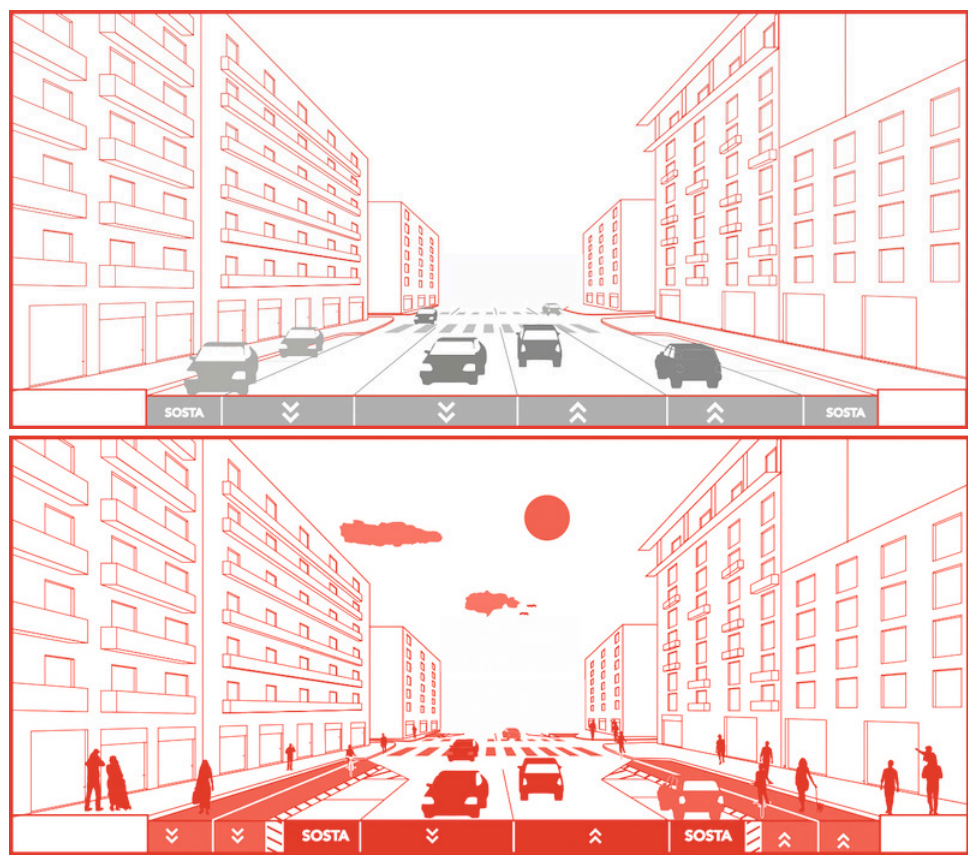

Figure 9. The proposed schematic road section for Buenos Aires Avenue, Milan.

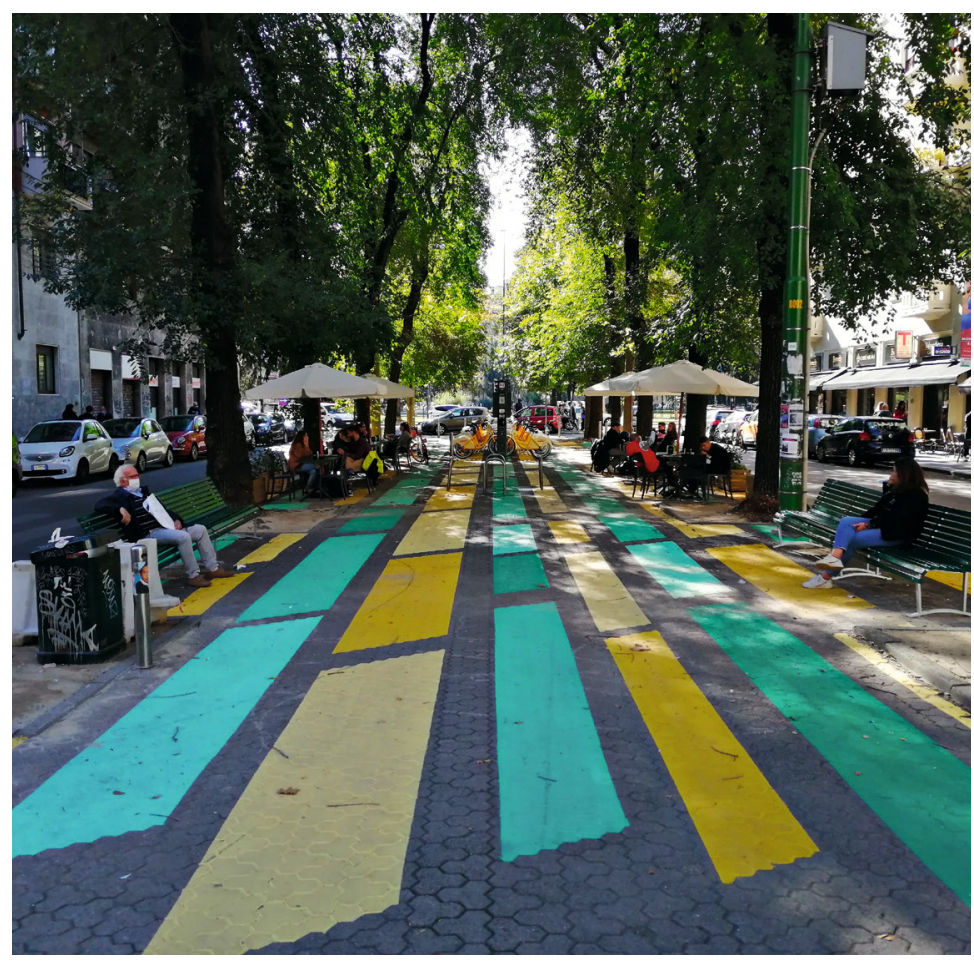

Figure 10. The

Tactical Urbanism intervention in Pacini Street, Milan. 


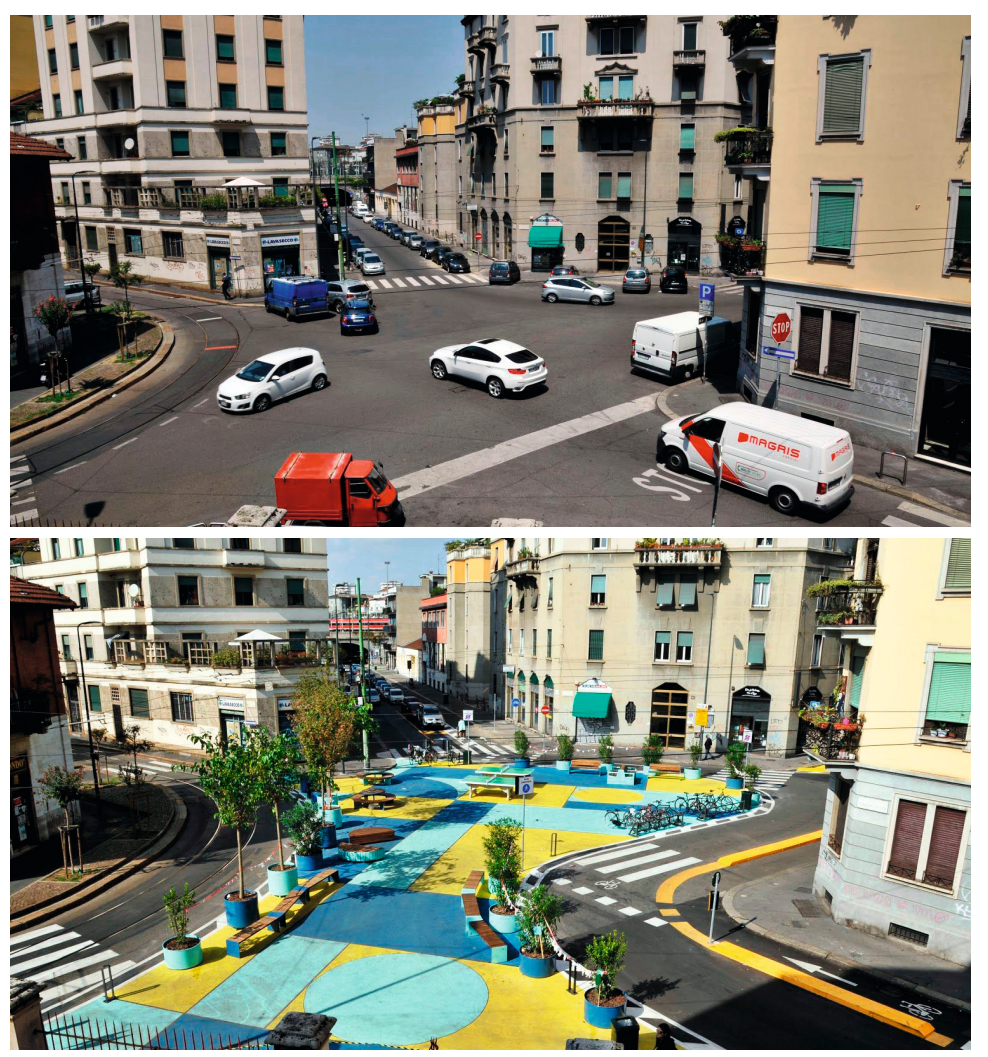

Figure 11. The Tactical Urbanism intervention in Spoleto Street, Milan, before and after.

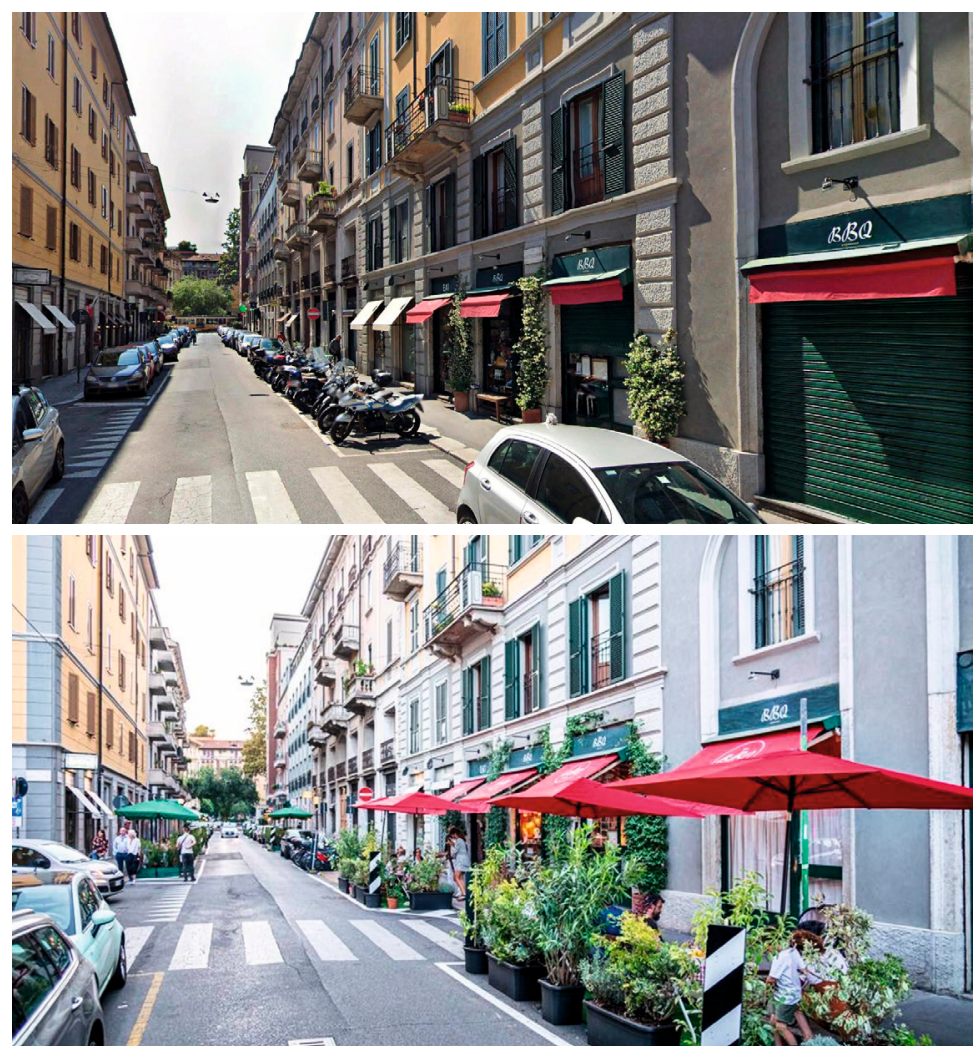

Figure 12. The Tactical Urbanism intervention in Sottocorno Street, Milan, before and after. 


\section{TOWARD A CONCLUSION}

It seems clear that even if there is no perfect solution that can answer the problems of the Global City, this can certainly be sought by analyzing the strategies recently developed to solve some of the short circuits inherent in contemporary urbanism. Born in the late-nineteenth century to ensure many people could live together in a healthy way on the basis of Georges Eugène Haussmann's theories, ${ }^{38}$ contemporary cities have developed differently according to local needs and policies, responding not only to the need for healthiness and coexistence, but also reflecting those control wills that, mild or strong, intercept and modify lifestyles and the way of experiencing public space. In a word, the way of relating to the contemporary city is based on regulations that determine the citizens' common living. But at the same time, citizens are called to react to redefine the new typologies of living together. The contemporary debate that embraces planning and architecture has long denounced how the Global City has particularities that make it a common factor at all latitudes: it is time to rediscover the importance of neighborhoods, of sociability, and of the interaction that takes place in the open spaces.

The outbreak of the COVID-19 pandemic has accelerated these considerations, promoting the need to move from theory to practice. For instance, long-term exposure to air pollutant concentrations is contributing to chronic lung inflammation, a condition that may increase the severity of Covid-19 effects. ${ }^{39}$ Reducing the reliance on cars is vital to enhancing Global Cities' liveability, along with tackling lower life expectancy and premature deaths due to environmental issues. The awareness that we will have to live with this disease that primarily affects the innate "sociality" of the human being as a social animal, has shown us how at the same time coexistence, living together, growing together is one of the fundamental bases of our species - a peculiarity that we all have in common. And precisely for this reason we are all called to reformulate the Global City concept, so that it becomes a common home where health is not an option but a standard.

Global Cities are nowadays claimed to be "cosmopolitan sites of mixing, as being at the sharp end of border technologies, structured by the often competing desires of firms, on the one hand, who only really have to consider the wage relation with their employees, and governments, on the other, who are increasingly driven by the technological costs of processing and maintaining migrant bodies." ${ }^{40}$ By this work, we are calling for updating their meaning in order to better include community, resilience, sustainability, and wellness through repetition, mix of uses and classes, and decentralization to help citizens satisfy basic needs and live healthier lives. In other words, Superblock and tactical urbanism should be included in the notion of Global City within the task of making it more sustainable, healthy and equal taking into account local peculiarities and operating always through participation. 
The solution comes from the flexibility and adaptability of what we already have available, which simply needs to be reinvented in the postCOVID-19 city. Barcelona, for example, is promoting a strong interaction between the local community and the administration without neglecting the market: the result is a rooted and identity system that personalizes what is "equal." On the contrary in China, the programmatic solution of the "gated communities," born from a political will to control the individual citizen, has proved useful to regenerate from scratch the concept of local (even "family") community typical of pre-revolutionary Chinese culture and to bring at the fore the discourse of the need for a bottom-up design of public spaces and their social function, starting a process that places new attention on the urban and landscape component of the internal areas between the high and dense residential towers. In Milan, on the other hand, the rediscovery of common living, which had already started before the arrival of the pandemic, had in the virus a powerful catalyst that in less than six months made it possible to reinvent the Lombard capital into an urban plot that can be crossed by bicycle on cycle paths that were not there before, with new public spaces where you can experiment with new forms of aggregation and transformation of social relations. And bearing in mind that all these different solutions are interchangeable, scalable, adaptable, in a word "universal," perhaps we are facing a new outline of the human being as a social being and as an urban dweller. The city was born to benefit the community. Now the community seems to be awakened and able, quickly, to impress new speeds and new lifestyles, which lead to a new resilient system and a healthy and open cohabitation. An open, hospitable and safe society.

\section{Notes}

1. Eduardo Aibar and Wiebe E. Bijker, "Constructing a City: The Cerdà Plan for the Extension of Barcelona," Science, Technology, and Human Values 22, no. 1 (1997): 3-30; Antoine Paccoud, "Planning Law, Power, and Practice: Haussmann in Paris (1853-1870)," Planning Perspectives 31, no. 3 (2016): 341-61.

2. Saskia Sassen, The Global City: New York, London, Tokyo (Princeton NJ, USA: Princeton University Press, 1991).

3. Jonas Bylund, Johannes Riegler, and Margit Noll, JPI Urban Europe - Strategic Research and Innovation Agenda 2.0. (Vienna: Urban Europe, 2019), 21-22.

4. The actual formulation of Tactical Urbanism is due to the studies by Mike Lydon and Anthony Garcia. Still, they just "reframed a set of core placemaking values (temporary, low-cost, flexible, iterative, participatory) found throughout history and updated them for the digital age." Anthony Garcia and Mike Lydon, Tactical Urbanism. Short-term Action for Longterm Change (Washington DC: Island Press, 2015), 25. The past references are in urbanism research by Jan Gehl and William Whyte and their studies about the social dimension of public spaces. Another theoretical basis is Nabeel Hamdi and his idea of "making plans without the usual preponderance of planning": see Nabeel Hamdi, Small Change: About the Art of Practice and the Limits of Planning in Cities (London: Earthscan, 2004), xix. According to the nonprofit organization Project for Public Spaces, the fundamentals of Tactical Urbanism have their roots in Eric Reynolds' claim "Lighter, quicker, cheaper" (Megan Maclver, Eric Reynolds, Master of Low-cost, High-return Public Space Interventions in London and NYC, August 8, 2010), which generated the so-called LQC approach. From a practical point of view, the process that showed Tactical Urbanism as a planning urban tool 
is the work by Janette Sadik-Khan as Commissioner of the New York City Department of Transportation from 2007 to 2013 (New York City Department of Transportation, Sustainable Streets: 2013 and Beyond, November 21, 2013). During her service, she implemented a series of fast, soft and ready-to-use intervention to transform road space into bike lanes and pedestrian plazas. Her most significant intervention is the process that led Times Square to become a pedestrian plaza.

5. Emily Skinner and Jeffrey R. Masuda, "Right to a Healthy City? Examining the

Relationship Between Urban Space and Health Inequity by Aboriginal Youth Artist-Activists in Winnipeg," Social Science \& Medicine 91 (2013), 210-18; Helen Cole, Margarita TrigueroMas, James Connolly, and Isabelle Anguelovski, "Determining the Health Benefits of Green Space: Does Gentrification Matter?," Health \& Place 57 (2019): 1-11.

6. C40 Cities, https://www.c40.org/other/covid-task-force.

7. Salvador Rueda et al., Ecological Urbanism: Its Application to the Design of an Eco-neighborhood in Figueres (Barcelona: Agencia de Ecología Urbana de Barcelona, 2014). See also: http://www.bcnecologia.net/en/conceptual-model/ecosystemic-urbanism. 8. The Cerda's Extension of Barcelona comprises 550 identical square blocks of $113.3 \mathrm{~m}$ [371 ft.] side in an orthogonal grid of identical $20 \mathrm{~m}$ [65 ft., $7 \mathrm{in}$.] wide streets with the exception of two diagonals and some minor streets.

9. Salvador Rueda, "Superblocks for the Design of New Cities and Renovation of Existing Ones: Barcelona's Case," in Integrating Human Health into Urban and Transport Planning, ed. Haneen Khreis and Mark J. Nieuwenhuijsen (Cham, Switz.: Springer International Publishing, 2019), 135-53.

10. Ajuntament de Barcelona, "Citizen Commitment to Sustainability - A More Sustainable Barcelona," 2012, https://ajuntament.barcelona.cat/ecologiaurbana/en/what-we-do-and-why/ public-commitment/citizen-engagement-network.

11. Ajuntament de Barcelona, https://ajuntament.barcelona.cat/superilles/es/superilla/ eixample\#.

12. Philippe Speranza, "A Human-Scaled GIS: Measuring and Visualizing Social Interaction in Barcelona's Superilles," Journal of Urbanism: International Research on Placemaking and Urban Sustainability 11, no. 1 (2018): 41-62; Jacopo Scudellari, Luca Staricco, and Elisabetta Vitale Brovarone, "Implementing the Supermanzana Approach in Barcelona. Critical Issues at Local and Urban Level," Journal of Urban Design 25, no. 6 (July 2019): 675-96; Natalie Mueller et al., "Changing the Urban Design of Cities for Health: The Superblock Model,” Environment International 134 (2020): 105-32; Iván López, Jordi Ortega, and Mercedes Pardo, "Mobility Infrastructures in Cities and Climate Change: An Analysis Through the Superblocks in Barcelona," Atmosphere, 11 (2020): 410; Christos Zografos et al., "The Everyday Politics of Urban Transformational Adaptation: Struggles for Authority and the Barcelona Superblock Project," Cities 99 (2020).

13. Ajuntament de Barcelona, "Supermanzana del Poblenou," 2018, https://ajuntament. barcelona.cat/superilles/es/content/poblenou; Public Space, "«Supermanzana» del Poblenou Barcelona (España)," 2018, https://www.publicspace.org/es/obras/-/project/k081poblenous-superblock.

14. Jacopo Scudellari, "Implementing the Supermanzana."

15. European Investment Bank, "Spain: EIB to provide $€ 95$ million to finance 40 climate action projects in Barcelona," August 3, 2020, https://www.eib.org/en/press/all/2020-215-eibto-provide-eur95-million-to-finance-40-climate-action-projects-in-barcelona.

16. Ajuntament de Barcelona, "El mercado inmobiliario de Barcelona. Precio de oferta de las viviendas de segunda mano," 2020, https://www.bcn.cat/estadistica/castella/dades/timm/ ipreus/hab2mave/index.htm.

17. Ajuntament de Barcelona, "El mercado inmobiliario de Barcelona. Contratos y precios registrados de las viviendas de alquiler," 2020, https://www.bcn.cat/estadistica/castella/ dades/timm/ipreus/habllo/index.htm.

18. http://noticias.juridicas.com/base_datos/CCAA/675381-I-11-2020-de-18-sep-ca-catalunamedidas-urgentes-en-materia-de-contencion.html.

19. Lee Pugalis et al., "Regeneration beyond Austerity: A Collective Viewpoint," Journal of Urban Regeneration and Renewal 7, no. 2 (2014): 188-97; Barbara Schonig and Sebastian Schipper, eds., Urban Austerity. Impacts of the Global Financial Crisis on Cities in Europe (Berlin: Theater der Zeit, 2016).

20. Thomas J. Campanella, The Concrete Dragon: China's Urban Revolution and What It Means for the World (New York: Princeton Architectural Press, 2012), 193. 
21. Giuliano Marrucci, Cemento Rosso. II Secolo Cinese, mattone dopo mattone (Milan: Mimesis, 2017); Jun Wang, Beijing Record: A Physical and Political History of Planning Modern Beijing (Singapore: World Scientific Publishing, 2011).

22. Leonardo Citterio and Joseph Di Pasquale, Lost in Globalization: The Paradigm of Chinese Urban Housing (Milan: Jamko Edizioni, 2015); Austin Williams, China's Urban Revolution, Understanding Chinese Eco-cities (London: Bloomsbury, 2017); You-tien Hsing, The Great Urban Transformation: Politics of Land and Property in China (Oxford, UK: Oxford University Press, 2010); Jiawen Han, China's Architecture in a Globalizing World: Between Socialism and the Market (London: Routledge, 2017).

23. Renee Y. Chow, Changing Chinese Cities: The Potentials of Field Urbanism (Singapore: NUS Press, 2015), 80.

24. Luca Maria Francesco Fabris and Gerardo Semprebon, "The Chinese 'High and Slender' Condominium," Techne - Journal of Technology for Architecture and Environment 17 (2019): 104-13.

25. Chow, Chinese Cities, 87.

26. Jean-Francoise Doulet, "Where Are China's Cities Heading? Three Approaches to the Metropolis in Contemporary China," China Perspective 4 (2008): 4-14.

27. As reported in an October 10, 2020 interview with Prof. FU Fan of the Beijing University of Civil Engineering and Architecture who testified that in the Superblock 中央民族大学社区 (Central University Faculty and Staff Community) during the COVID-19 emergency there was only one gate open for all the community of 6,000 individuals. At the gate eleven staff employees tested temperature and tracked entries and exits. This simple action provided both to keep the pandemic out of the Superblock and gave a sense of confidence to the whole community. Official data from the Chinese authorities is not available at the moment. 28. The PGT is a new kind of city master plan in Italy that defines urban rules and future developments. The PGT was adopted by the Milan Municipality with City Council Deliberation on May 16, 2012.

29. Comune di Milano, "Piazze Aperte in ogni quartiere," January 25, 2020, accessed August 4, 2020, https://www.comune.milano.it/documents/20126/71248910/200213_ Piazze+Aperte_slideshow_light+compressed.pdf/c2a2b36f-8c23-b7e0-d9cf6bcf58c4663f?t=1581589429841.

30. Ibid.

31. Demetrio Scopelliti (Former advisor to Deputy Mayor for Planning, Green and Agriculture), interview by the authors, July 15, 2020.

32. Janette Sadik-Khan and Seth Solomonow, Streetfight: Handbook for an Urban Revolution (New York: Viking Press, 2016), 19.

33. Many articles appeared on the international press debating the Milan response to COVID-19 pandemic, including on The Guardian, CNN and Bloomberg.

34. Comune di Milano, AMAT, "Strade Aperte. Strategie, azioni e strumenti per la ciclabilità e la pedonalità, a garanzia delle misure di distanziamento negli spostamenti urbani e per una mobilità sostenibile," May 2020, accessed August 4, 2020, https://www.comune.milano. it/documents/20126/992518/Strade+Aperte_IT_200430_rev.pdf/a100d04c-6b55-ae74-e0f8b52563e07822?t=1589460655416.

35. Vivienne Walt, "'We Heard Birds.' Paris Mayor Anne Hidalgo on How Lockdown Offered a Glimpse at a Greener City,” Time, July 9, 2020, accessed July 28, 2020, https://time.com/5864707/paris-green-city/.

36. Filippo Bozzoni et al., "Access to Green Areas and Public Realm: The Case of Milan" (Milan: Systematica Srl, 2020), accessed July 28, 2020, https://research.systematica.net/ research/access-to-green-areas-and-public-realm-the-case-of-milan/; Filippo Bozzoni et al., "Local: Mapping Milan Micro-Centers" (Milan: Systematica Srl, 2020) accessed July 28, 2020, https://research.systematica.net/journal/living-local-mapping-milan-micro-centers/. 37. Deliberations of the City Council no. 13, May 14, 2020, accessed August 4, 2020 , https://www.comune.milano.it/repo/sillecto/files/015146/2020/015146_2020_268629.pdf. 38. Giandomenico Amendola, Sguardi sulla città moderna. Narrazioni e rappresentazioni di urbanisti, sociologi, scrittori e artisti (Bari, It.: Dedalo, 2019).

39. Eric S. Coker et al., "The Effects of Air Pollution on COVID-19 Related Mortality in Northern Italy," Environmental and Resource Economics 76 (2020): 611-34. 40. Donald McNeill, Global Cities and Urban Theory (London: Sage, 2017), 10. 


\section{References}

Ajuntament de Barcelona. "Superilles. El Poblenou," 2018. https://ajuntament.barcelona.cat/ superilles/es/content/poblenou.

Bazzu, Paola and Valentina Talu. Tactical Urbanism 5 - Italy. Sassari, It.: TaMaLaCà, 2016; $2^{\text {nd }}$ ed. 2017.

Bylund, Jonas, Riegler Johannes and Noll Margit. JPI Urban Europe - Strategic Research and Innovation Agenda 2.0. JPI Urban Europe, 2019. https://jpi-urbaneurope.eu/app/ uploads/2019/02/SRIA2.0.pdf.

Campanella, Thomas. The Concrete Dragon: China's Urban Revolution and What It Means for the World. New York: Princeton Architectural Press, 2012.

Chow, Renee Y. Changing Chinese Cities: The Potentials of Field Urbanism. Singapore: NUS Press, 2015.

Citterio, Leonardo, and Joseph Di Pasquale. Lost in Globalization: The Paradigm of Chinese Urban Housing. Milan: Jamko Edizioni, 2015.

Cole, Helen, Margartia Triguero-Mas Margarita, James Connolly, and Isabelle Anguelovski. "Determining the Health Benefits of Green Space: Does Gentrification Matter?" Health and Place 57 (2019): 1-11. Doi: 10.1016/j.healthplace.2019.02.001

Comune di Milano, AMAT, "Strade Aperte. Strategie, azioni e strumenti per la ciclabilità e la pedonalità, a garanzia delle misure di distanziamento negli spostamenti urbani e per una mobilità sostenibile." May 2020. Accessed August 4, 2020. https://www.comune milano.it/documents/20126/992518/Strade+Aperte_IT_200430_rev.pdf/a100d04c-6b55 ae74-e0f8-b52563e07822?t=1589460655416.

Comune di Milano. "Piazze Aperte in ogni quartiere." January 25, 2020. Accessed August 4, 2020. https://www.comune.milano.it/documents/20126/71248910/200213 Piazze+Aperte_slideshow_light+compressed.pdf/c2a2b36f-8c23-b7e0-d9cf$6 b c f 58 c 4663 f ? t=1581589429841$.

Doulet, Jean-Francois. "Where Are China's Cities Heading? Three Approaches to the Metropolis in Contemporary China." China Perspective 4 (2008): 4-14.

Fabris, Luca Maria Francesco, and Gerardo Semprebon. "The Chinese 'High and Slender' Condominium'." Techne - Journal of Technology for Architecture and Environment 17 (2019): 104-13.

Garcia, Anthony, and Mike Lydon. Tactical Urbanism. Short-term Action for Long-term Change, vol. 1 and 2. New York: The Street Plans Collaborative, 2012.

- - . Tactical Urbanism: Short-term Action for Long-term Change. Washington DC: Island Press, 2015.

National Association of City Transportation Officials, Streets for Pandemic Response and Recovery. New York: NACTO, 2020. Accessed August 4, 2020. http://www.street-plans. com/streets-for-pandemic-response-and-recovery/.

Gehl, Jan. Life Between Buildings: Using Public Space. First Danish edition of 1971, translated by Jo Koch. New York: Van Nostrand Reinhold, 1987.

Hamdi, Nabeel. Small Change: About the Art of Practice and the Limits of Planning in Cities. London: Earthscan, 2004.

Hsing, You-tien. The Great Urban Transformation: Politics of Land and Property in China. Oxford, UK: Oxford University Press, 2010.

Maclver, Megan. "Eric Reynolds, Master of Low-cost, High-return Public Space Interventions in London and NYC." Project for Public Spaces. August 8, 2010. Accessed August 4, 2020. https://www.pps.org/article/eric-reynolds-master-of-low-cost-high-return-publicspace-interventions-in-london-and-nyc.

New York City Department of Transportation. Sustainable Streets: 2013 and Beyond. November 21, 21013. Accessed August 4, 2020. https://www1.nyc.gov/html/dot/ downloads/pdf/2013-dot-sustainable-streets.pdf.

Sadik-Khan, Janette, and Seth Solomonow. Streetfight: Handbook for an Urban Revolution, New York: Viking Press, 2016.

Sassen, Saskia. The Global City: New York, London, Tokyo. Princeton NJ, USA: Princeton University Press, 1991.

Skinner, Emily, and Jeffrey R. Masuda. "Right to a Healthy City? Examining the Relationship Between Urban Space and Health Inequity by Aboriginal Youth Artist- Activists in Winnipeg." Social Science \& Medicine 91 (2013): 210-18. Doi: 10.1016/j.socscimed.2013.02.020. 
Soni, Nikhi,I and Neetishree Soni, 2016. "Benefits of Pedestrianization and Warrants to Pedestrianize an Area." Land Use Policy 57 (2016): 139-50.

Systematica (Filippo Bazzoni, Giulia Boni, Rawad Choubassi, and Dante Presicce). "Access to Green Areas and Public Realm: The Case of Milan." Milan: Systematica Srl, 2020. https://research.systematica.net/research/access-to-green-areas-and-public-realm-thecase-of-milan/.

Systematica (Filippo Bazzoni, Lamia Abdelfattah, Oxana Borovkova, Rawad Choubassi, Diego Deponte, Jonelle Hanson, Matteo Marconi, Dante Presicce, and Marianna Zuretti). "Living Local: Mapping Milan Micro-centers." Milan: Systematica Srl, 2020. Accessed July 28, 2020. https://research.systematica.net/journal/living-local-mapping-milan-microcenters/.

Walt, Vivienne. " 'We Heard Birds.' Paris Mayor Anne Hidalgo on How Lockdown Offered a Glimpse at a Greener City." Time, July 9, 2020. Accessed July 27, 2020. https://time. com/5864707/paris-green-city-2/.

Whyte, William. The Social Life of Small Urban Spaces. Washington DC: Conservation Foundation, 1980.

Williams, Austin. China's Urban Revolution: Understanding Chinese Eco-Cities. London: Bloomsbury, 2017.

\section{Acknowledgments}

The whole paper is the product of a common research work by the four authors. However, the various parts are to be attributed as follows: Prof. Fabris had the role of proposal and research coordinator and contributed to edit the final version of the article and wrote the Introduction and the Conclusions; Dr. Camerin wrote the parts dedicated to Barcelona; Dr. Semprebon wrote the parts dedicated to Beijing; and Riccardo Maria Balzarotti wrote the parts illustrating the Milan response to COVID-19. Federico Camerin has participated as co-author within the frame of the European Joint Doctorate "urbanHIST," European Union. This project has received funding from the European Union's Horizon 2020 research and innovation program under the Marie Skłodowska Curie grant agreement No. 721933.

\section{Credits}

Figures 1-4: photos by (c) Federico Camerin, 2020.

Figures 5-8: photos courtesy of (c) Professor FU Fan, 2020.

Figures 9 and 11: images by (C) Comune di Milano, AMAT, "Strade Aperte. Strategie, azioni e strumenti per la ciclabilità e la pedonalità, a garanzia delle misure di distanziamento negli spostamenti urbani e per una mobilità sostenibile," p. 28 and p. 9 respectively.

Figure 10: photo by (c) Luca Maria Francesco Fabris, 2020.

Figure 12: photo retrieved from Google Earth Pro, 2019 (above); photo courtesy City of Milan, 2020 (bottom).

Table 1: elaboration by the @ Authors, 2020. 
Luca Maria Francesco Fabris, architect, PhD, is an Associate Professor in Environmental Design at the Politecnico di Milano, where he teaches in the architecture and landscape architecture master's programs. Currently, he is also a Beijing University of Civil Engineering and Architecture "Haiju" Expert - 北京建筑大学海聚专家.

E-mail: lucamariafrancesco.fabris@polimi.it

Federico Camerin is a city planner (2014), with a PhD degree (2020) from the urbanHIST consortium. His research focuses on the European city-making process starting from the late nineteenth century onwards, the regeneration of dismissed military real estate assets, megaevents and urban transformations, as well as the star-architects' role in the built environment management. E-mail: federico.camerin@uva.es

Gerardo Semprebon, architect, PhD at Shanghai Jiao Tong University and Politecnico di Milano, where, since 2018, is a Research Fellow at the Department of Architecture and Urban Studies. His research has a focus on design strategies for the revitalization of rural settlements with particular regard to China and Italy. E-mail: gerardo.semprebon@polimi.it

Riccardo Maria Balzarotti, architect, holds a master's degree from the Politecnico di Milano, where he is currently a Fellow Researcher at the Department of Architecture and Urban Studies since 2017. He is a founding partner of the Milanese architectural firm AOUMM, established in 2012. E-mail: riccardomaria.balzarotti@polimi.it 